\title{
8
}

\section{Response to Stephen Davis}

John B. Cobb, Jr.

Stephen Davis is afraid that my position diverges from the Christian tradition by failing to affirm that God is the cause of the existence of all material things. He agrees with me that this does not mean that God is the ultimate material cause. But he thinks that 'if there would be no material reality apart from God then God is ultimate in the line of material causes'.

Our dispute seems to be verbal. I agree that apart from God there could be no material thing, or any other kind of thing. God is a necessary cause of the existence of any thing whatsoever. My point is that God is not the only necessary cause of the existence of things. Things require a 'material cause' as well.

This does not mean that there exists alongside of God another being. The material cause is not a being. It does not exist in separation from the beings or things of which God is a necessary cause. I am not affirming a dualism. But the fact that a material cause is also necessary for the existence of things has not been thematized in the Christian tradition. I am consciously trying to develop and modify the tradition, but I am not breaking with it in the way Davis fears. 